\title{
A STUDY ON POLITENESS STRATEGIES OF CHARACTERS IN THE BIG WEDDING MOVIE DIRECTED BY JUSTIN ZACKHAM
}

\author{
Ferdianita Lucky Nur Safitri (Corresponding Author) \\ Fakultas Bahasa dan Sastra Universitas Kanjuruhan Malang \\ Jl. S. Supriyadi 48 Malang, Indonesia \\ Phone (0341) 801488 (ext. 341) e-mail:- \\ Mujiono \\ Fakultas Bahasa dan Sastra Universitas Kanjuruhan Malang \\ Jl. S. Supriyadi 48 Malang, Indonesia \\ Phone (0341) 801488 (ext. 341) e-mail:- \\ Siane Herawati \\ Fakultas Bahasa dan Sastra Universitas Kanjuruhan Malang \\ Jl. S. Supriyadi 48 Malang, Indonesia \\ Phone (0341) 801488 (ext. 341) e-mail:-
}

\begin{abstract}
In every place have some unwritten rules depend on the countries, beside people use a language, they use a politeness also. Politeness is important thing that people must know when they communicate with other people and make a polite conversation. Politeness strategies are used to formulate messages in order to save hearer's face when face-threatening acts are invitable or desire. Brown and Levinson stated four main types of politeness strategies: bald on-record, positive politeness, negative politeness, and off-record (indirect). In this study is intended to analyze politeness strategies that used by characters in "The Big Wedding Movie". There is a problem that is discussed in this study (1) what politeness strategies are used on "The Big Wedding Movie"? (2) why do characters in "The Big Wedding Movie" use politeness strategies? This analysis focus on the politeness strategies that used by characters in the conversation of "The Big Wedding Movie".
\end{abstract}

The researcher applied the qualitative research and used descriptive methods in this study because all data are in the form of words. Meanwhile, the type of the research is content analysis because it intended to analyze the content of the data which are in the form of movie script to find the politeness stretegies. When analyze the data, the researcher used the theory of Brown and Levinson about politeness strategies.

Based on the result of the analysis, it is found that there are eighty six utterances that use four politeness strategies. They are bald on-record with twenty nine utterances, positive politeness with thirty eight utterances, negative politeness with ten utterances, and off-record with twelve utterances. The most frequently used politeness is positive politeness, bald on-record, off-record, and the less frequently used is negative politeness. 
For supporting the study, the researcher needed source of the theories related to politeness strategies such as : bald on-record, positive politeness, negative politeness, and off-record (indirect). From the findings, the researcher expected that the result of this study will useful for English learners to get the information from politeness strategies found in the movie of "The Big Wedding Movie".

Key words : Politeness strategies, characters, the big wedding movie.

\section{Introduction}

As a social creatures and human beings, people need a tool to make interaction, to communicate with other people. It is called language. Widdowson (2002:4), language is a purely human and non-instinctive method of communication ideas, emotion and desires by means of system of voluntarily produced symbol.Language can facilitate us to inform a good or bad news to other. Besides to communication, people use language to get information about everything. For example, education, politics, entertainment, social issues and so on. If we do not use a language, according to Chaer and Agustina (1995:19), it seems impossible for people to interact with other in daily life because language can express people's feeling, willing, option, etc. As a result, we will understand what people want and they too.

According to Wardhough in jurnal of Yuni Murliati (2013), by this language, people try to manage to live together by using such concept as 'identity', 'power', 'class', 'status', 'solidarity', 'accomodation', 'face', 'gender', 'politeness', etc. Furthermore, language is an inheritance from our ancestor because they has studied in the past. Although, they still use a symbols, that is their ways to communicate with their society. Nowadays, in our world, there are so many kinds of language. Our language influenced by our ancestor, so that make one place with the others have different language, different characters and different pronountition. In a conversation, there are have some unwritten rules depend on the countries.

Like the researcher said before, in every place have some unwritten rules depend on the countries, include at home, school, or work environment, beside we use a language, we use a politeness also. Politeness is important thing that we must know when we communicate with other people and make a polite conversation. Politeness is not only used to honor to old people, but also it can be used to give honor to young people. It is indicate who we are, whether we are a good people or not, and includes people who respect to other people or not.

Murliati (2013) states politeness is a behaving in a way that attempts to take into account the feelings of the people being addressed. It is one of important subject matters in a communication. Politeness is an important factor in developing effective relationships with people, and any misuse of these strategies can hinder the effective communication, leading to individuals dissatisfaction and indifference (Reza Pishghadam, 2012). Using strategies of politeness properly can control our selves when we communicate with other. If we talk 
with high intonation and rude, the communication will not good enough.

Brown and Levinson (1978), politeness is basic to the production of social order and a precondition of human cooperation. Therefore, we must be careful to choose the strategies of politeness when we make an interaction because someonewho talk with us can be misunderstanding. Politeness have two types and four strategies.

Two different types of politeness are used in interaction; "negative politeness" and "positivepoliteness". Brown and Levinson defined the negative politeness as "a redressive action addressed tothe addressee's negative face: his want to have his freedom of action unhindered and his attentionunimpeded (1987:129).

Whereas the positive politeness isdefined as "redress directed to the addressee's positive face, his perennial desire that his wants (orthe actions/acquisitions/values resulting from them) should be thought of as desirable" (1987:101).

Politeness strategies itself include : bald-on record strategy, positive politeness strategy (showing respect), negative politenes $\mathrm{s}$

strategy (showing solidarity), and off recordstrategy. Each one have the purpose which is appropriate with the situation or with whom we will talk.

According to Watts (2003:1), some might characterise a polite person as always being considerate towards other people; others might suggest that a polite person is self-effacing. Thus, if we being polite, many people feel comfortable and do not hesitate to make relation with us, although just talk for a moment. Also, with being polite, we can keep our relationship and feeling with other people. In here, being polite can be indicate with the expression of face, control our speech, gesture, and many more.

In addition, the politeness strategies also used in literary work like novels, drama or films. Especially for dramas or films, it takes from real life. Many films adopted from the real story and appeared as an interesting film, like love stories or story about political, patriotism, social and so on. In dramas or films, the important points about politeness are more than easy to understand because we can wacth directly without having to imagine it. So that, we can choose which one is good or not good for us to apply in daily life.

Based on the reason, the researcher will be analized the politeness strategies because the researcher interested about it in The Big Wedding Movie's dialogues. The writer chooses this movie because the characters are usedin the movie is politeness strategies.Such as they talk, for example one of characters in this movie use a positive politeness to show her disillusion when she heard a bad news with offered a tea.

The Big Wedding Movie is a American comedy film written and directed by Justin Zackham in 2013. This film told about family that has some problem like common family in America. The story of film is one family that has a lot of problem just to hold the wedding last son in this family. Although, this film only played for 90 minutes, The Big Wedding film is scattered by big stars and got $\$ 35,770,721$ for Box Office.

In this study, the researcher wants to deeply learn about pragmatic especially politeness in Big Wedding Movie. The researcher will observe the 
politeness strategies that used by all of characters include :bald-on record strategy, positive politeness strategy, negative politeness strategy, and off recordstrategy in this movie.

Based on the explanation above, the researcher wants to study about politeness strategies of characters that used in Big Wedding Movie.

\section{METHODOLOGY}

\section{Research Design}

According to Clarke and Clarke (2010), research is a careful, systematic and objective investigation conducted to obtain valid facts, draw conclusion and established principles regarding an identifiable problem in some field of knowledge. Another perception, Mouley (2010) stated research is a systematic and objective analysis and recording of controlled observations that may lead to the development of generalizations, principles, theories and concepts, resulting in prediction for seeing and possibly ultimate control of events.

This study attempted to obtain information concerning politeness strategies that used by characters in The Big Wedding Movie. This study was directed toward describing those aspects. Therefore, the design of this study was qualitative research and the researcher employs descriptive method.Meanwhile, the type of the research is content analysis because it intended to analyze the content of the data which are in the form of movie script to find the politeness stretegies.

Bodgan and Taylor (in Septyaningsih, 2007) define qualitative research as a research that presents the descriptive data in the form of written or oral words of people and behavior which can be observed. As a result, this research did not measure the data gathered into nominal scale and need no enumeration or quantification.

Besides, the researcher uses descriptive method. Surakhmad in Septyaningsih (2007) states that descriptive method is a kind of research method using technique of searching, collecting, classifying, analyzing the data, interpreting them and finally drawing conclusion.

The conclusion in descriptive method is conducted without making generalizing. From some views above, so thats why the researcher try to describe and analyze the politeness strategies. Therefore, the researcher collects the data, analyzes and interprets them, and draw conclusion about the kinds of politeness strategy, and the factors influencing characters to employ this strategy.

\section{FINDINGS}

\section{Politeness Strategies Are Used On The Big Wedding Movie}

The researcher found four types that used by characters in The Big Wedding Movie, they are : bald onrecord strategy, positive strategy, negative strategy, and off record strategy.

But, the researcher would introduce all characters first to make easy understanding the analysis. Don is a father in Griffin family, he has exwife namely Ellie and has a girlfriend namely Bebe who live with him in the 
house. From the first wedding, Don has three child, Lyla, Jared and his adopted son, Alejandro. This family will be held the wedding for their son, Alejandro with his mate, Missy. Before wedding is happen, some problems presents in this family, for example from the biological mother's Alejandro, Madonna who very infexibel, from Missy parents, Barry O'Conner and Muffin, etc.

\section{Bald On-Record}

Bald on-record is a type of politeness strategy used by the speaker when he does not intend to minimize the FTA to the hearer. The researcher found 25 utterances that contain bald on-record. In this movie, the characters used three cases such as : speaker speaks as maximum efficiency is very important, speaker want to satisfy hearer's face is small, and speaker conveys that he cares about hearer.

a) speaker speaks as maximum efficiency is very important,

\section{Datum 2}

Bebe :Well, that is the point.It's not supposedto come up in conversation.

Don : How about chowing box?(2)

Bebe : Stop it, Donald!

In this dialogue Don used bald on-record to the hearer because Don used language which only him and the hearer mutual know that language. Also, with used this strategies, Don gots the hearer's attention. The researcher also found in datum 3, 4, 36, and 64 (see Appendix).

b) speaker want to satisfy hearer's face is small,

\section{Datum 5}

Don : Cunnilingus.

Bebe : You are such a slut. (5)
In this conversation, dialogue for Bebe, she used bald on-record, also she put in positive face. This strategies also applied in 10,17, 23, 26, 29, 30, $31,35,49,47,48,50,54,58,71,72$, 73, and 84. (see Appendix). It is more than used because the characters sometimes like to embarrass or get a shock to the hearer.

c) speaker conveys that he cares about hearer.

\section{Datum 18}

Lyla : What?A bevy of hot nursesare conspiring to bang your brains out?You should press charges.No, not my brother.He's gotta wait for love. (16)

Jared : Yeah, well...It seemed likea really noble idea when I was 15.Anyway, I'm starting to waver.

In this situasion, especially in datum 16, Lyla used bald on-record strategy because she cares with her brother.

\section{Positive Politeness}

Positive politeness are used to show what hearer's wants is speaker's wants too. Also, politeness strategies shared togetherness to make solidarity. In this film, the characters almost using the positive politeness, because the resercher found 38 utterances and used strategies such as : notice, exaggerate, common membership, seek agreement, token agreement, white lies, joke, be optimistic, ask for reason, and giving gift to $\mathrm{H}$.

\section{a) Notice, attend to $\mathrm{H}$}

\section{Datum 22}

Bebe : Right?And I'm catering it. Organic, of course.Oh, God, I was just so terrified to see you.

Ellie : Oh, don't be (20).I mean, look, it was a long time ago.

In datum 20, the researcher analyze if Ellie used positive politeness 
and used notice strategy. Not only datum 20, but also in datum 37, 43, 74, and 80(see Appendix) the researcher find positive politeness that used notice strategy.

\section{Datum 7}

\section{b) Exaggerete,}

Ellie : Hi, Bebe.

Bebe : Hi.

Ellie : You look... You look wonderful (7)

Ellie used positive politeness because she gave stress when she said "wonderful". In datum 12, 19, 21, 28, 53, 70, and 78 (see Appendix), it is used positive politeness also.

\section{c) Intensify interest to $\mathrm{H}$}

\section{Datum 1}

Don : What do I use in its place?You know (1),when it comes up in conversation.

Bebe :Well, that is the point.It's not supposedto come up in conversation.

In this dialogue, Don used positive politeness and appropriate with Brown and Levinson theory as intensity interest to H.Meanwhile, in datum 52 and 65 (see Appendix) also used this politeness strategies.

\section{Datum 8}

d) Common membership in a group

Bebe : Honey (8), why don't youtake her up to the Embroidery Room.I'm gonna round up some sheets.

Don : At your service, madame. Right this way.

Bebe used positive politeness because sheclaim in-group membership with hearer. The researcher also found in datum 11, 24, 25, 27, 42, and 82(see Appendix).

\section{Datum 62}

e) Seek agreement

Alejandro: You really truly love me.

Missy : I do.

Alejandro: Yeah, you do (60).

Missy : And you'll fix all the other stuff?
Dialogue above contains with positive politeness which is the speaker seek agreement with the hearer because Alejandro as a speaker repeat what Missy as a hearer said before. In datum 67 (see Appendix), it is same with dialogue above but different characters.

\section{Datum 65}

f) Token agreement

Don : Yeah, so we picked up another kidto avoid the issue. You know, I tried to stick it out. I really did.

Ellie : I know you did, Don (63).

In dialogue above, Ellie used positive politeness strategy, where she appear to agree or pretending to agree.

g) White lies

\section{Datum 14}

Alejandro: Oh, God.

Father Michigan: Yes?

Missy : What?

Alejandro:Sorry. Nothing. It's fine (13).

In datum 13, Alejandro used positive politeness, especially in white lies. White lies used in datum 55 and 56(see Appendix). Alejandro used this politeness because he wants to serve the hearer's face, Missy.

h) Joke

\section{Datum 51}

Jared : Careful.We've had shark problems in the past (49).

Nuria : Freshwater sharks?

Jared : Touche. May I?

The dialogue above contains about positive politeness especially in a joke. Also, this strategy occur in datum 45 and 68 (see Appendix).

i) Be Optimistic

\section{Datum 81}


Ellie : Come on, you were my best friend.Still are, I hope (79).Oh, Bebe. It wasn't him.Oh, yeah, okay, so he was flirting, but I made the first move.

Ellie used positive politeness that contains with be optimistic strategy. It is also in datum 77(see Appendix).

j) Asking reason

\section{Datum 41}

Don : Why don't we just fake itfor a of couple days? (39) No big deal.

Ellie : And what makes either of youthink you could pull this off?

In here, Don used positive strategy where he asking the reason. This strategy showed that Don and Ellie included in a activity.

\section{k) Giving gift to $\mathrm{H}$}

\section{Datum 68}

$\begin{array}{ll}\text { Nuria } & \text { : A performance? } \\ \text { Jared } & \text { : Item one.Serenade her (66). } \\ & \text { ( singing a song ) } \\ & \text { There's not a lot of words } \\ & \text { that rhyme with Nuria } \\ & \text { But I really want to } \\ & \text { Reassure ya } \\ & \text { That I will try not to be } \\ & \text { Premature-ia }\end{array}$

In this dialogue in datum 66 and also in datum 9 and 59,Jared used positive politeness especially giving gift to hearer (see Appendix).

\section{Negative Politeness}

Negative politeness is also known as a respect politeness where every partisipant not to be disturbed and to be free. For this movie, it is the less frequently appear because therearche found 9 utterancesthat used negative politeness andonly two strategies was found that is give deference with 1 utterance and beg forgiveness with 8 utterance.
a) Give deference

\section{Datum 20}

Ellie : You were so wonderful to them (18). Bebe : Well, they're not officially my kids, but, you know...God, you look stunning.

In this dialogue in datum 18, Ellie used negative politeness becauseshe gave appreciated to the hearer, Bebe.

b) Beg forgiveness

\section{Datum 6}

Ellie : Oh, my God. I don't...Really, I'm so terribly sorry (6).He told me that nobody was here.And I don't know why he did.The key was over...Anyway, I'm just...I'm gonna...Y You know what I'm gonna do?

Bebe : Oh, my goodness. Ellie?

In datum 6, Ellie used negative politeness because her act is positive, beg forgiveness. This strategy also included in datum 14, 15, 62, 69, 75, 81, and 83 (see Appendix).

\section{Off-record}

Off-record has the main purpose of taking some pressure off of the hearer. off-record also known to speak indirect. Sometimes, when speaker speaks, he would use vague manners and has more than one meaning. The characters not always used this politeness stratgy, it indicated with 12 utterances that used off-record and divide in five strategies, such as : use tautologies, use contradiction, be ironic, be ambiguos, and be incomplete or use ellipsis.

a) Use tautologies 
Datum 24

Don :Hey. Look at you two.Haven't seen this much tail around heresince the last poochie died (22).

Don applied one of ways the theory of Brown and Levinson that off recordespecially intautologies strategy.It is also applied in datum 33 (see Appendix).

b) Use contradiction

\section{Datum 63}

Don : Kids are great.You're having ninehour orgasms.

Ellie : No, no, no, just... Yeah, well, give or take (61)

Don : I'm intrigued.

Ellie used off record especially used contradiction because it showed two different things.

c) Be ironic

\section{Datum 36}

Lyla : Yeah. Thought you were afraid of heights.

Don : The heights are fine.It's the lows I'm not in love with(34)

Dialogue above;in datum 34, Don used off record which emphasized with using ironic.It is also used in datum 40, 44, 51, and 57.
d) Used ambiguos

\section{Datum 78}

Muffin : They're both equally delicious

Jared : And that's the ballgame. Wow. I did not see that one coming. (76).

On the dialogue above, in datum 76, Jared used off-record to gave therespond to what has been said before by Muffin.

e) Use incomplete

\section{Datum 34}

Lyla : You know what?As long as it's come up,let's just get it overwith.Because I'm sure Barry and Muffin hereare just dying to hear all aboutthe tests, and the injections, and humiliation. I've so enjoyed the last four years.

Barry : No, we really don't... (32)

Muffin : shhhh ... !

Barry used off record strategy. He speaks not complete, it is called ellipsis where the speaker hang up his words.It is used to in datum 38 and 41 ( see Appendix).

\subsubsection{Why characters in The Big Wedding Movie use politeness strategies}

As appropriate with research problem, after the researcher analyze what politeness strategies used by characters in The BigWedding Movie, then, the researcher would analyzed and explaine why characters use those politeness strategies.

\section{Bald On-Record}

a) speaker speaks as maximum efficiency is very important,

\section{Datum 2}

Bebe :Well, that is the point.It's not supposedto come up in conversation.

Don : How about chowing box?(2)

Bebe : Stop it, Donald.

In this dialogue where speaker, Don and hearer, Bebe in the kitchen and speaker wants something important, he want to kissing. Therefore, Don used bald on-record because he wants to gets the attention from Bebe, also the speaker wants the hearer understand directly without the speaker explain or talks clearly.

b) speaker want to satisfy hearer's face is small, 
Datum 5

Don : Cunnilingus.

Bebe : You are such a slut. (5)

Dialogue above, the situasion stillin the kitchen but Bebe who used bald on-record.She used that politeness because she wants to be rude, but not really serious or it means if she wants to deliver a joke. She said like in datum 5 because the hearer wants to make love with her and she wants too but she shine to confess it.

c) speaker conveys that he cares about hearer.

\section{Datum 16}

Lyla : What?A bevy of hot nursesare conspiring to bang your brains out?You should press charges.No, not my brother.He's gotta wait for love. (16)

Jared : Yeah, well...It seemed likea really noble idea when I was 15.Anyway, I'm starting to waver.

Dialogue above contains with bald on-record because in datum 16 , it shows that Lyla cares with Jared, her brother who still virgy and still wait the true love and he already waver. Lyla shows her cares with ask to her brother to make a press charges in spite of she just tried to regale him.

\section{Positive Politeness}

a) Notice, attend to $\mathrm{H}$

\section{Datum 20}

Bebe : Right?And I'm catering it. Organic, of course.Oh, God, I was just so terrified to see you.

Ellie : Oh, don't be (20).I mean, look, it was a long time ago.

In datum 20, Ellie used positive that shows notice to the speaker, Bebe. Ellie just tried to calm Bebe down. They are a bestfriend but in the past they has a problem but Ellie never worried about that, so she wants that her friend never thought again. b) Exaggerete,

\section{Datum 7}

Ellie : Hi, Bebe.

Bebe : Hi.

Ellie : You look... You look wonderful (7)

In datum 7, Ellie used positive politeness. She said "wonderfull" with exaggerete intonation because she was getting shock and long time no see her friend, Bebe.

\section{Datum 1}

c) Intensify interest to $\mathrm{H}$

Don : What do I use in its place?You know (1), when it comes up in conversation.

Bebe :Well, that is the point.It's not supposedto come up in conversation.

In this dialogue, Don used intensify interest to the hearer. To gets all attention and to make the hearer interest in speaker with made a good conversation.

d) Common membership in a group

\section{Datum 8}

Bebe : Honey (8), why don't youtake her up to the Embroidery Room.I'm gonna round up some sheets.

Don : At your service, madame. Right this way.

Datum 8 contains with politeness strategy especially in common membership in a group. For example in a word like,"honey", "sweety", "darling" and many more it is used to soften the request.

\section{e) Seek agreement}

\section{Datum 60}

Alejandro: You really truly love me. Missy : I do.

Alejandro : Yeah, you do (60).

Missy : And you'll fix all the other stuff?

Dialogue above, in datum 60 , Alejandro used seek agreement with repeat part of what the preceding Missy has said in a coversation. He wants to 
make convincing between himself and the hearer,Missy.

\section{Datum 63}

f) Token agreement

Don : Yeah, so we picked up another kidto avoid the issue.You know, I tried to stick it out. I really did.

Ellie : I know you did, Don (63).

Ellie appear to agree because to avoid the disagreement with Don, her ex-husband. Shejust want to succumb and did not want to damage the good situasion at there, especially with Don.

g) White lies

\section{Datum 13}

Alejandro: Oh, God.

Father Michigan: Yes?

Missy : What?

Alejandro:Sorry. Nothing. It's fine (13).

The reason why Alejandroused white lies like in datum 13 is to avoid disagreement between he and the hearer, Missyit is better to lie than make a disagreement and make condition like the hearer wants.
h) Joke

\section{Datum 49}

Jared : Careful.We've had shark problems in the past (49).

Nuria : Freshwater sharks?

Jared : Touche. May I?

The dialogue above, in datum 49, Jared use positive politeness and make a joke to get intimate the relationship between himand Nuria, Alejandro's sister. Therefore, Jared was success to make Nuria interest ti him. Eventhough Nuria did not smile directly,it is enough to make close relationship.

i) Be Optimistic

\section{Datum 79}

Ellie : Come on, you were my best friend.Still are, I hope (79).Oh, Bebe. It wasn't him.Oh, yeah, okay, so he was flirting,but I made the first move.

Ellie still has high conviction if she and her friend still friend, although Bebe had divulge her secret and told people in wedding party. Ellie still hope if she and Bebe never change their friendship.

\section{j) Asking reason}

\section{Datum 39}

Don : Why don't we just fake itfor a of couple days? (39) No big deal.

Ellie : And what makes either of youthink you could pull this off?

When Don speaks like in datum 39 above, it is asking the reason. Despite of in the same time he gaves the suggestion. He just wants to make everything simple and he did not want to make complicated. So, Don asked to Ellie to lie for three days as a couple in fact they has divorce.Therefore, this strategy showed that Don and Ellie included in a activity.

\section{k) Giving gift to $\mathrm{H}$}

\section{Datum 66}

Nuria : A performance?

Jared : Item one.Serenade her (66). ( singing a song )

There's not a lot of words that rhyme with Nuria But I really want to

Reassure ya

That I will try not to be Premature-ia

In datum 66, it is strategy to give gift to hearer and dialogue above contains with it. Although, Nuria was not applied negative face, Jared gave the song to fullfill some Nuria's wants because he wants to made their relationship closer. 


\section{Negative Politeness}

a) Give deference

\section{Datum 18}

Ellie : You were so wonderful to them (18), Bebe : Well, they're not officially my kids,but, you know...God, you look stunning.

In datum 18, Ellie used negative politeness which is having honor to Bebe. Because she reduce herself and gave the prise to Bebe.The main purpose when Ellie used negative politeness and used give deference strategy is appreciated to the hearer.

b) Beg forgiveness

\section{Datum 6}

Ellie : Oh, my God. I don't...Really, I'm so terribly sorry (6).He told me that nobody was here.And I don't know why he did.The key was over...Anyway, I'm just...I'm gonna...Y You know what I'm gonna do?

Bebe : Oh, my goodness. Ellie?

Ellie said sorry because she has the hearer getting shock. Although, Ellie did not drive at the hearer when they did something.

\section{Off-Record}

a) Use tautologies

\section{Datum 22}

Don :Hey. Look at you two.Haven't seen this much tail around heresince the last poochie died (22).

Don used tautologies in his utterance which is contain with implisit meaning. He did not want damage the harmony between his ex-wife andhis girlfriend. So that, he said "Haven't seen this much tail around heresince the last poochie died" because he never see both of themin togetherness.

b) Use contradiction

\section{Datum 61}

Don : Kids are great.You're having ninehour orgasms.

Ellie : No, no, no, just... Yeah, well, give or take (61)

Don : I'm intrigued.

Ellie used off-record especially used cotradiction when she has getting shockfrom Don. After she said "no", but suddenly she said "yes". It showed two different things. Ellie could knows if she speaks the truth directly, her exhusband would flirt her.

c) Be ironic

\section{Datum 34}

Lyla : Yeah. Thought you were afraid of heights.

Don : The heights are fine.It's the lows I'm not in love with (34)

In datum 34, Don used ironic to hide his feeling. In fact, he afraid of heights but he still triedtoride the board to accompany his daughter who felts despondent.

d) Be ambiguos

\section{Datum 76}

Muffin : They're both equally delicious

Jared : And that's the ballgame. Wow. I did not see that one coming. (76).

In the datum 76 , the researcher analysed if Jared used ambiguos strategy because what he said not really has conotasion clearly. "And that's the 
ballgame" it can be the ending from many problem before and "I did not see that one coming" it can be the surprise if Muffin is a lesbian.

\section{e) Use incomplete}

\section{Datum 32}

Lyla : You know what?As long as it's come up,let's just get it overwith.Because I'm sure Barry and Muffin hereare just dying to hear all aboutthe tests, and the injections, and humiliation. I've so enjoyed the last four years.

Barry : No, we really don't... (32)

Muffin : shhhh ... !

Barry could not continue his speak like in datum 32 because his wife orders him tosilent. Actually, he really honest if he and his wife did not want to know what happened to Lyla but he failed.

\subsection{Dicussion}

After finding the politeness that used by characters and why thecharacters use politeness strategies proposedby Brown and Levinson theories inThe Big Wedding Movie, this section presented the discussion of the result of finding section. So, the researcher presented two subdivisions, politeness are used by characters and why the characters use politeness strategies.

\section{CONCLUSION Conclusion}

Politeness strategies are the method of communication used by the speaker to maintain the hearer's face to get the goal. Based on Brown and Levinson's theory of politeness strategies, there are four types of politeness strategies namely bald onrecord, positive politeness, negative politeness, and off record. In this study, the researcher found all the types of politeness strategy that covered in 84 data. Although, all of strategies are not found, all types are applied in The Big Wedding Movie.

There are some strategies found in each type :

1. Bald On-Record is a politeness strategy that does not intent to minimize the impact of the FTA for the hearer. The researcher found condition in which maximum efficieny used in 5 data, the situasion in which speaker's want to satisfy hearer's face is small used in 19 data, and the condition in which speaker conveys that he cares about hearer used in 1 data.

2. Positive Politeness is a kind of politeness strategy that is used to satisfy the hearer's face. There are found 5 data using notice, 7 data using exaggerete, 3 data using intensify interest to hearer, 6 data using speaker may stress membership in a group or category, 2 data using seek agreement, 3 data using white lies, 3 data using joke, 2 data using optimistic, 1 data using give or ask reason, and the last 2 data using giving gifts to hearer.

3. Negative Politeness is used least of other types of politeness strategies. It is the speaker action addressed to the hearer's face, the want to be freedom. For this type found give deference in 1 data and beg forgiveness in 8 data.

4. Off-Record is communicative act which is not clear or more has interpretation (indirect). And this strategy found 5 strategies : 2 data in tautologies, 

ironic, 1 data in ambiguos. 


\section{References}

Bariyah, Khusnatul. 2014. Politeness strategies used by Characters in Brenda Chapman's "Brave”. Thesis. Faculty of Teacher Training and Education English Department. Kajuruhan University Kanjuruhan of Malang.

Brown, Penelope and Stephen C. Levinson. 1987. Politeness: Some Universals In Language Usage. Cambridge: Cambridge University Press.

Fitriyana, Yuli. 2007. Politeness Strategies In John Grisham's Novel "The Client”. Thesis. English Letters and Language Department. Humanities and Culture Faculty. The State Islamic University of Malang.

Grace, Yefune. 2014. Politeness Strategies Found in The Movie of Ramona and Beezus. Thesis. Faculty of Teacher Training and Education English Department. Kajuruhan University Kanjuruhan of Malang.

Huang, Yongliang. 2008. Politeness Principle in Cross-Culture Communication. Publised by: English Language Teaching Journal

Kádár, Dániel Z. and Michael Haugh. 2013. Understanding-Politeness. Cambridge University Press, New York

Miles, M. B. \& Huberman, A. M. 1994. Qualitative Data Analysis: An Expanded Sourcebook. 2nd Edition. New York: SAGE Publications Inc.

Murliati, Yuni. 2003. Politeness Strategies Used By George Milton In Jhon Steinbeck's of Mice And Men. Graduating Paper. State Islamic Uneversity Sunan Kalijaga, Yogyakarta

Ningsih, Irma Ratna. 2012. An Analysis Of Politeness Strategies Used By Harry PotterIn J.K. Rowling's Novel "Harry Potter And The Sorcerer's Stone”. English Education Department Of Tarbiyah Faculty OfSyekh Nurjati State Institute For Islamic Studies, Cirebon 
Pishghadam, Reza and Safoora Navari. 2012. A Study into Politeness Strategies and Politeness Markers in Advertisements as Persuasive Tools. Journal. Mediterranean Journal Of Social Sciences

Septyaningsih, Ani. 2007. An Analysis Of Positive Politeness Strategy In The Film Entitled "In Good Company"(A Pragmatics Study). Thesis. Faculty Of Letters And Fine Arts Sebelas Maret University, Surakarta.

Watts, Richard J.2003. Key Topics In Sociolinguistic:Politeness. Cambridge University Press, New York

Yuka, Akutsu. 2009. Positive Politeness Strategies In Oral Communication vol.52. Journal. The Economic Journal of Takasaki City University of Economics. 